\title{
The assessment of commercial flights emissions at Ordu-Giresun Airport, Turkey
}

\author{
I. Orhan ${ }^{1, *}$ \\ ${ }^{1}$ Eskisehir Technical University, Faculty of Aeronautics and Astronautics, Turkey
}

\begin{abstract}
Ordu-Giresun International Airport is Turkey's first and world's second airport built on the sea. This study provides the pollutant gas emitted from aircraft with carbon monoxide (CO), hydrocarbons ( $\mathrm{HC})$, and nitrogen oxides (NOx) during landing and take-off cycles in Ordu-Giresun International Airport in 2015. It also presents the fuel burnt. For emission calculation, ICAO's database for aircraft engine emission data and General Directorate of State Airports Authority's database for flight records were used. In the calculations, a sensitivity analysis was made by taking into consideration the aircraft types and engine types used by the airline companies on the flights to Ordu-Giresun International Airport.
\end{abstract}

\section{Introduction}

Air transportation continues to grow with an increasing momentum from the past to the present. The passengers prefer as a priority transportation option with its fast mode of transportation between cities and countries. With the development of countries economic and welfare levels of people, the demand for tourist, commercial and cargo air transport is expected to continue to increase in the future. In 2017, 4.1 billion people made air travel in scheduled passenger transport worldwide. This figure means a $7.3 \%$ increase compared to 2016 [1]. According to IATA's 2017 report, in 2036, 7.8 billion passengers will travel using the airline [2].

In 2018,12 million passengers are expected to carry out 120,000 flights daily. The $\$ 6$ trillion goods transported in the airline industry in 2017 account for $35 \%$ of international trade. Globally, 57\% of international travels are made by airline. In 2017, 341 billion litres of jet fuel, worth $\$ 149$ billion, was used by commercial airlines. As a result, 859 million tons of carbon dioxide emissions were released in 2017 [3].

Kesgin [4] analysed exhaust emissions in the LTO (Landing and Take-off) phase that consists of four modes of engine operation, namely idle, approach, climb out and take-off in 40 Turkish national and international airport. In 2001, it was estimated that an average of 7614.34 to 8338.79 tons of exhaust emissions were produced annually during the LTO phase. In addition, it is stated that there is a $6 \%$ reduction in the exhaust emission of the LTO phase by reducing the taxi time by 2 minutes [4]. Tinmaz and etc [5] examined the exhaust emission values of the airplanes coming to Corlu Airport during the LTO phase. Yllmaz [6] made

\footnotetext{
*Corresponding author: iorhan@eskisehir.edu.tr
} 
emission analysis in Kayseri Airport according to the data of the years of 2010. It was calculated that $8.4 \mathrm{t} / \mathrm{y}$ for $\mathrm{HC}, 66.90 \mathrm{t} / \mathrm{y}$ for $\mathrm{CO}$, and $102.64 \mathrm{t} / \mathrm{y}$ for NOx were emitted during landing and take-off mode. Kuzu [7], estimated landing and take-off cycle emission at Atatürk International Airport and modelled the dispersion of emissions. The emissions of NOx, CO and $\mathrm{HC}$ were found as 4249, 2153, and 181t/y, respectively. It was shown that most of the airport areas and the residential area of the west of the airport exceeded the limit of NOx value annually. Postorino and etc [8] examined the taxi-out operation with stakeholders to reduce the emission of $\mathrm{CO} 2$ and propose some precautions to airport operation management.

In this study, the estimation of pollutant gas emissions of aircraft in LTO process in OrduGiresun Airport was investigated. ICAO - Engine emission database is used for emission calculations, and General Directorate of State Airports Authority's database for flight records in 2015 was used.

\section{The calculation of aircraft emissions and air traffic at Ordu- Giresun airport}

\subsection{Ordu-Giresun Airport}

Ordu-Giresun Airport is located in the Black Sea region of Turkey, close to the city center of Ordu and Giresun. The provinces of Ordu and Giresun are among the provinces that give a large amount of immigration both in Turkey and abroad. The majority of people working abroad and engaged in domestic migration are still in contact with their hometown. This is of great importance for the international passenger potential of the airport. Similarly, in Istanbul, Ankara, Bursa, Izmir and Kocaeli, a significant number of citizens live in Ordu and Giresun. Considering the fact that Ordu-Giresun Airport has a regional character, this situation is also crucial for the passenger potential of the airport. It is expected that Ordu and Giresun will become a preferred location for those interested in green and touristic areas and those interested in nature and extreme sports. The airport was opened in 2015 and has an annual capacity of 3 million passengers (Figure 1). Passenger and aircraft traffic information for the years between 2015 and 2019 is shown in Figure 2 and Figure 3 for Ordu-Giresun Airport.

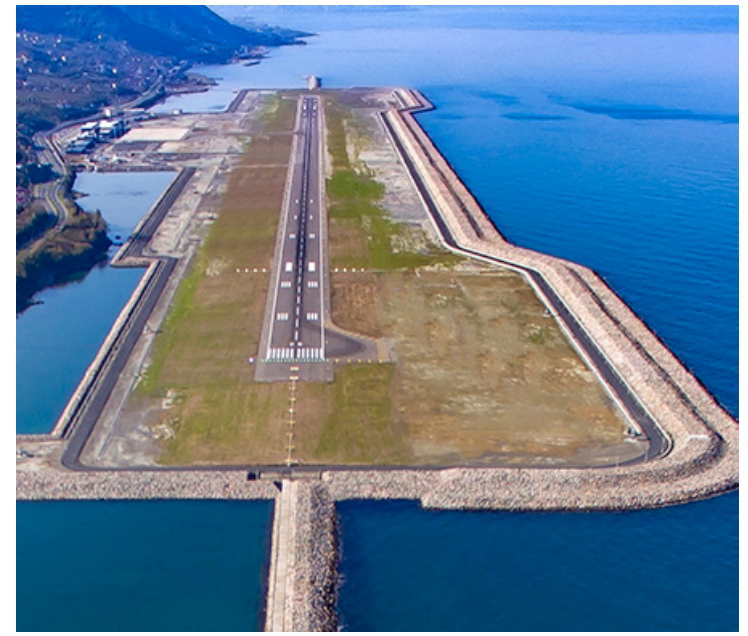

Figure. 1. Ordu-Giresun Airport [9] 


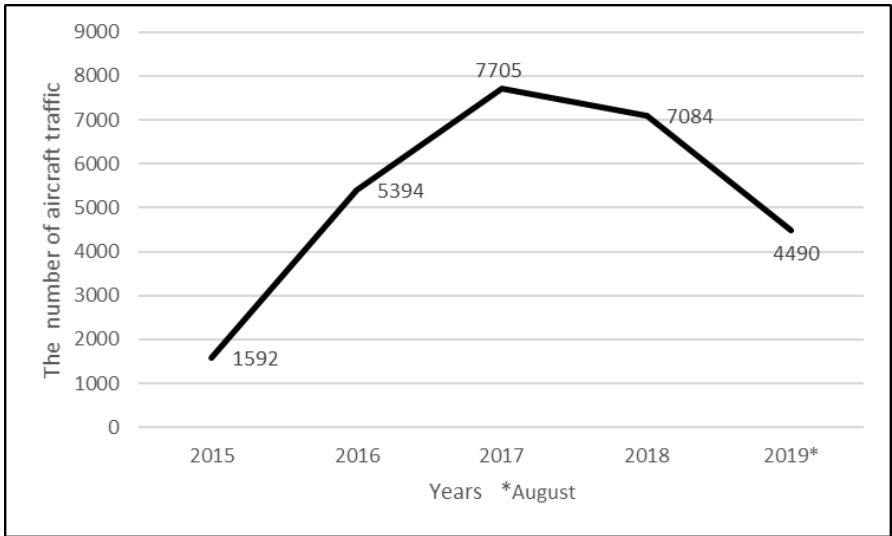

Figure. 2. The number of aircraft traffic at Ordu-Giresun Airport between 2015 and 2019 [10]

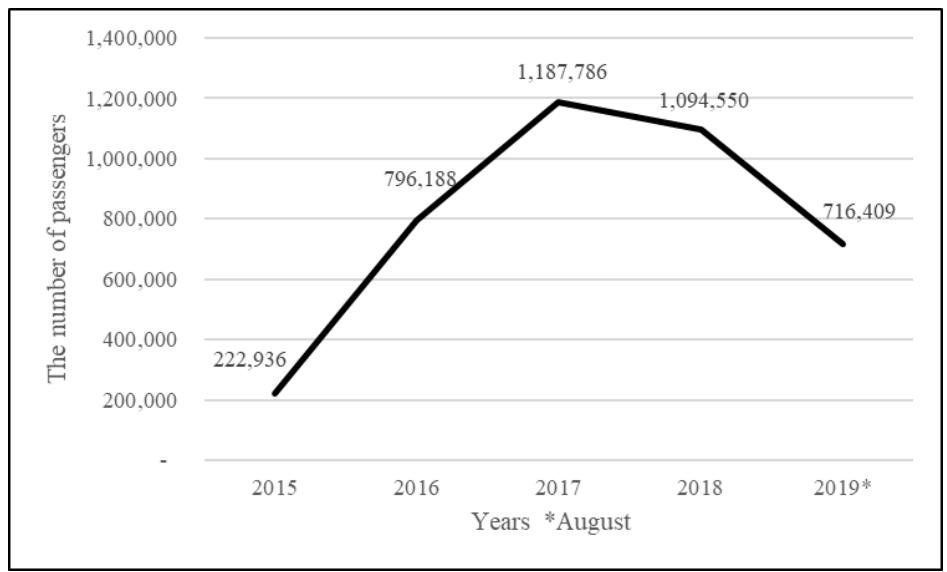

Figure. 3. The number of passenger at Ordu-Giresun Airport between 2015 and 2019. [10]

\subsection{Methodology and Calculation}

The amount of emissions emitted and the amount of fuel consumed by an airplane in the landing and take- off cycles varies depending on many variables such as weather conditions, traffic density at the airport and the types of aircraft using the airport and the time the aircraft spends for the required power in the cycle. The landing take-off cycle defined by ICAO is shown schematically in Figure 4.: Approach, taxi, take-off, climb.

According to the ICAO engine emission certification procedure, the LTO cycle comprises the following power setting and time-in mode [11].

- Take-off: $100 \%$ thrust for 0.7 minutes

- Climb: $85 \%$ thrust for 2.2 minute

- Approach: $30 \%$ thrust for 4 minutes

- Taxi: $7 \%$ thrust for 26 minutes. Taxi consists of two parts taxi-in and taxi-out

The approach consists of operations on the airport from $3000 \mathrm{ft}$ until the planes reach the runway. The taxiing phases consists of the maneuvers of the aircraft up to the take-off position and those that are blocked until it reaches the runway threshold. Take-off includes 
the process from runway threshold to aircraft rotation. The climb includes from rotation until the plane reaches $3000 \mathrm{ft}$.

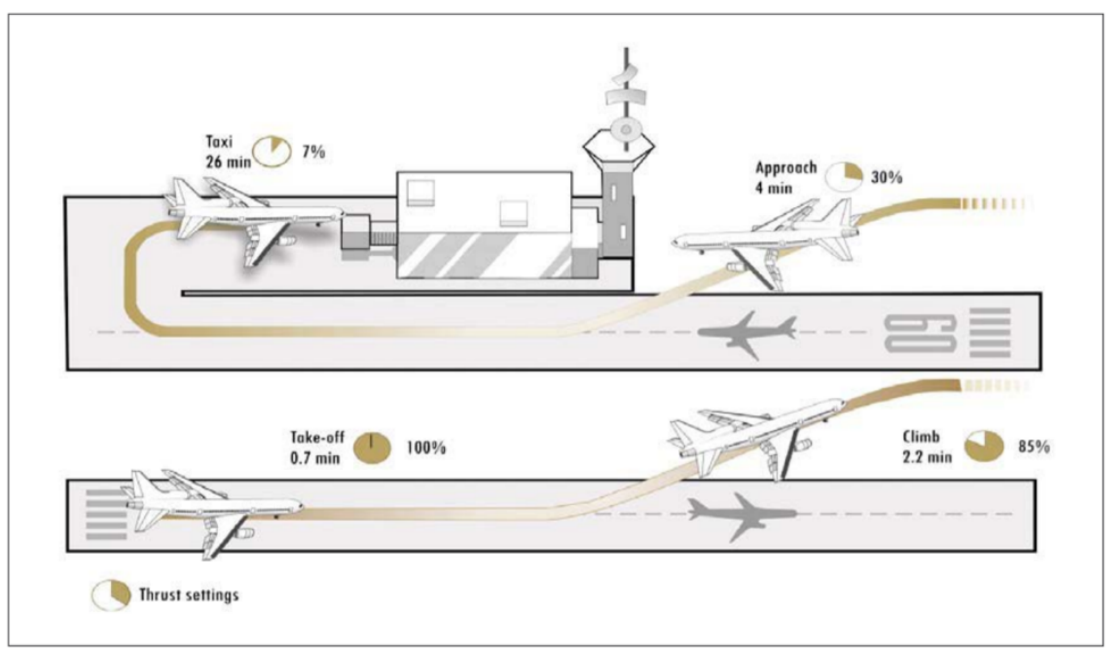

Figure. 4. The landing take-off cycle [12]

The fuel consumption and emission indices of an aircraft for each operating mode are taken from the ICAO-Engine emission database [13]. The equations (1) is used for emissions calculation $(4,14,15)$;

$$
E_{i, m}=\sum_{a} \sum_{e} n_{a} l_{a, e} F_{a,} E_{e, m, i} t_{m, a}
$$

Where $E_{(i, m)}$ is annual emission of pollutant $i$ for mode $m,(\mathrm{~kg} / \mathrm{yr}) ; n_{a}$ is the number of engines of aircraft type $a ; l_{(a, e)}$ is the number of annual LTO cycles for aircraft type $a$ with engine type $e ; F_{a, e, m}$ is fuel consumption for aircraft type with engine type $e$ in mode $m,(\mathrm{~g} / \mathrm{kg})$; $E_{(e, m, i)}$ is emission factor for engine type $e$ and mode $m$ and pollutant $i,(g / k g)$ and $t_{(m, a)}$ is time in mode $\mathrm{m}$ for aircraft type $a,(s)$.

Ordu-Giresun Airport was opened on May 22, 2015 and 1592 commercial flights operated in its first year. According to 2015 data, the aircraft used in the commercial flights to the airport and the engine types used in the aircraft is shown in Table 1.

Table 1. The aircraft with engine type used for flight Ordu-Giresun Airport

\begin{tabular}{|l|l|}
\hline A320-200 & CFMI CFM56-5B4/3 \\
\hline B737-800 & CFMI CFM56-7B24 \\
\hline B737-800 & CFM56-7B27 \\
\hline B737-800 & CFM56-7B26 \\
\hline B737-800 & CFM56-7B26E \\
\hline
\end{tabular}

\section{Results and conclusion}

In this study, the pollutant emissions and the amount of fuel consumed during the LTO cycle at Ordu-Giresun Airport in 2015 are considered. The mass of fuel burnt, the mass of CO, HC and NOx that emitted were calculated and presented in Table 2. 
Table 2. The aircraft with engine type used for flight Ordu-Giresun Airport

\begin{tabular}{|l|r|}
\hline Mass of fuel burnt $(\mathrm{kg})$ & $1,387,485.31$ \\
\hline Mass of CO emitted $(\mathrm{kg})$ & $14,375.86$ \\
\hline Mass of HC emitted $(\mathrm{kg})$ & $1,083.52$ \\
\hline Mass of NOX emitted $(\mathrm{kg})$ & $17,537.58$ \\
\hline
\end{tabular}

The demand for air transport increases with an annual average increase of 5\% around the world. The increasing number of flights due to passenger demand will be one of the significant causes of air pollution in the airport area. At the airport, emissions analysis from airplanes was conducted in the year the airport was started to operate, with relatively low air traffic. Accordingly, because of the lack of heavy traffic, the taxi duration of the aircraft will also be less than ICAO's time-in-mode values, thus reducing the emission rates in part. Emissions emitted from aircraft will increase due to increased taxi time at the airports, stop and go flights, and the amount of power required for the return movements. Providing faster and more direct taxi routes with fewer stops may be the first step to reduce emissions at the airport. Compared to the previous years, although the use of new aircraft and new engines, emissions are still lagging behind the targets, partly due to the fact that old technology engines are still in use. With the development of combustion and engine technology and aircraft designs, efforts are underway to further reduce emissions in the future. However, minimizing potential delays at airports will also contribute to reducing emissions.

\section{References}

1. Rosen, E. Over 4 Billion Passengers Flew In 2017 Setting New Travel Record. (2018) https://www.forbes.com/sites/ericrosen/2018/09/08/over-4-billion-passengers-flew-in2017-setting-new-travel-record/\#235f8c2a255b

2. IATA. 2036 Forecast Reveals Air Passengers Will Nearly Double to 7.8 Billion. (2017). https://www.iata.org/pressroom/pr/Pages/2017-10-24-01.aspx

3. ATAG. Aviation Benefits beyond Borders. https://aviationbenefits.org/media/166344/abbb18_full-report_web.pdf

4. Kesgin U., Aircraft emissions at Turkish airports, Energy, 31, 372-384, (2006)

5. Tınmaz E, Özkan A, Akpınar A., Aircraft originated air pollution in the example of Çorlu airport, Journal of Environmental Protection and Ecology, 3 (3), 586-592, (2002)

6. Y1lmaz, İlker., Emissions from passenger aircraft at Kayseri Airport, Turkey, Journal of Air Transport Management, 58, 176-182, (2017)

7. Kuzu, S. Levent., Estimation and dispersion modeling of landing and take-off (LTO) cycle emissions from Atatürk International Airport, Air Quality, Atmosphere \& Health, 11(2), 153-161, (2018)

8. Postorino, Maria Nadia, Luca Mantecchini, and Filippo Paganelli., Improving taxi-out operations at city airports to reduce CO2 emissions, Transport Policy 80, 167-176, (2019)

9. https://www.airporthaber.com/ordugiresun-havalimani-haberleri/, (2019)

10. https://www.dhmi.gov.tr/sayfalar/istatistik.aspx, (2019)

11. International Civil Aviation Organization, Exhaust emission data bank, Doc. 9646AN/943, Montreal, CA, (1995). See also www.icao.org. 
12. ICAO, Environmental Report Aviation And Environment, (2019) https://www.icao.int/environmental-protection/Documents/ICAO-ENV-Report2019F1-WEB\%20\%281\%29.pdf

13. ICAO Aircraft Engine Emissions Databank, (2019) https://www.easa.europa.eu/easaand-you/environment/icao-aircraft-engine-emissions-databank

14. Stefanou, P., and D. Haralambopoulos, Energy demand and environmental pressures due to the operation of Olympic Airways in Greece, Energy, 23.2, 125-136, (1998)

15. Ekici, S., Yalin, G., Altuntas, O., Karakoc, T. H., Calculation of HC, CO and NOx from civil aviation in Turkey in 2012, International Journal of Environment and Pollution, 53 (3-4), 232-244, (2013) 